\title{
Water and merit goods
}

\section{In response to the paper by Marco Schouten and Klaas Schwartz, "Water as a political good: implications for investment" (see pp. 407-421)}

\section{J. B. (Hans) Opschoor}

Received: 31 August 2006/Accepted: 4 September 2006/

Published online: 25 October 2006

(C) Springer Science+Business Media B.V. 2006

\section{Introduction}

Water is essential to life. Its availability is a crucial factor in human well being. Its provision therefore is a key societal concern-both the level and the distribution of it. Views on the provision of water to users fall within two opposite categories: (a) water as a purely private economic good best provided through markets, and (b) water as a good the access to which is to be guaranteed as a human right.

Water issues are multi-layered. First, water is a consumption good (and an intermediary input in production). But, second, it does not fall out of the sky as manna, according to need. Water originates from the water cycle or water system, the direct manifestation of which (in the form of pools and other reservoirs, rivers etc.) I refer to here as 'water resources'. Water resources (e.g. catchments, basins, etc.) play significant roles in the provision of ecosystem functions and services. Third, in between water as a good and water resources are water provision systems and mechanisms: the 'water services' sector or industry.

Schouten and Schwartz are concerned with two of these levels: water and water services, especially with investments in the latter. They wonder why these continue to fall short of expressed needs. They use a conceptual framework (economic goods-'political goods') that is worth looking at in some depth before commenting on their views on investment in water services.

\subsection{Water as an economic good}

Dublin Principle No. 4 (adopted at the International Conference on Water and Environment, Dublin 1992) states "[w]ater has an economic value in all its

J. B. (Hans) Opschoor ( $\square)$

Institute of Social Studies, Rockanjelaan 35, 2554 BP The Hague, The Netherlands e-mail: opschoor@iss.nl

J. B. (Hans) Opschoor

Vrije Universiteit, Amsterdam, The Netherlands 
competing uses and should be recognized as an economic good". ${ }^{1}$ The Organization on Economic Co-operation and Development (OECD) had already defined water as an 'economic good' because (scarce) economic resources (human, capital, knowledge) have to be applied to the natural resource in order to make water available in the form, quality, location and time users need it (OECD, 1987, pp. 18, 129; see below). Indeed, the provision of water comes at an effort, a cost, and so does the preservation of the hydrological and ecological systems that would make for its sustained availability.

In dominant thinking it is the user who is to pay the cost of the provision of water ('user pays principle'), as should be the case for any other economic good. One key question is whether market mechanisms can be relied upon to generate the correct price to pay for water, and hence, whether the water sector can be privatized.

Economic theory holds that the appropriate concept of cost of provision is that of 'opportunity costs', which consist of: (i) the resource use costs in the operation and maintenance of the water supply system; (ii) the qualitative and quantitative natural resource depletion costs; and (iii) any externalities the operation of the supply system gives rise to (OECD, 1987, pp. 18, 19). One way of making these manifest would be through a well functioning market for water as a commodity, that is: a situation where well informed users and (all!) beneficiaries of the preservation of water resource systems would deal with a supply side that would reflect all these elements of the opportunity cost. But in reality markets do not conform to this ideal. To begin with, water provision often is a technologically advanced activity, with monopolistic features (indivisibilities and associated decreasing marginal costs, exclusive property rights, etc.). Moreover, water use and water 'production' have externalities attached to them (i.e. positive and negative social costs and benefits) and resource depletion costs not captured at all in the operation and maintenance cost calculations of private suppliers. These are all examples of 'market failures' that make for public intervention in water markets.

Thus, acknowledging water to be an economic good by no means implies that its provision is to be left to market mechanisms or to market forces. Theoretically, markets alone are appropriate provision mechanisms under certain conditions. One condition is that the goods in question are private goods: economic goods that are 'rival in consumption' (consumption by one precludes consumption by others) and with 'excludable benefits or costs' (others beyond the actual user can be excluded from benefiting or suffering as a consequence of his/her use). Goods are public in consumption when either one of these properties (or both) are not met; public decisions about their provision are then appropriate due to 'provision problems' (see e.g. Kaul, Conceicao, le Goulven, \& Mendoza, 2003, pp. 92,155). Water as such was typically seen as an impure public good: a common pool resource that is nonexcludable but rival in consumption. But the non-excludability is being contested (e.g. through privatization of sources) or by-passed (e.g. through separable access like taps in homes, or provision in bottled form), making water as a consumption good take on more aspects of a private good (see e.g. Mehta, 2003) for a broader analysis of the evaporation of the common goods character of water). Still, the more basic ecological functions or services provided by water resources (i.e. the regulatory and carrier functions) are public goods.

\footnotetext{
${ }^{1}$ Not everyone seems clear on what the notion of water as an economic good means (e.g. Savenije and Van der Zaag, 2001; Schouten and Schwartz, this volume consider that to be vague). 
In the economic literature on provision, allocation and pricing, even when the public goods nature of water or elements of the water resource system is recognized, reference usually is to individual preferences for these goods and services as the ultimately decisive yardstick. This is often called 'consumer sovereignty'.

One of the provision problems mentioned, is that of under consumption due to lack of means (Kaul et al., 2003, p. 155); an unfair distribution of income may stand in the way of having adequate "access to clean water and sanitation at an affordable price" (as Dublin Principle 4 called for). As far back as in 1987, OECD (1987, 14ff.) documents mentioned the need to have 'social pricing' of water, so as to not preclude any consumer by financial considerations from enjoying the benefits of water. This point leads to some wider considerations. Inappropriate income distributions have been long recognized as a 'market system failure' related argument for public intervention (cf. Musgrave, 1959). This could be done through direct redistribution, or by subsidizing certain types of expenditure (such as e.g. in the field of water) by lower income strata. There is now a dominant preference for the former approach and against allowing 'price distorting' subsidies. It is interesting to see that the OECD in 1987 was less radical than a neo-liberal stance would imply (OECD, 1987, 26ff., 122). ${ }^{2}$

\section{Water, markets and merit considerations}

So, several features of water provision call for intervention even on the basis of consumer sovereignty: market failures such as externalities and market system failures such as skewed income distributions. But there is more: in certain cases intervention in provision and pricing is (seen as) justified on grounds beyond consumer sovereignty, namely social or public views on appropriate provision to the different categories of stakeholders/beneficiaries. Such goods have been labeled '(de-)merit goods' as, because of some perception on their desirability, individual choice is put aside or at least corrected (Musgrave, 1959). Grounds for such corrections include ignorance, irrationality and inadequate time and risk preference. Drugs, milk for children and safety belts are the usual examples. The point is, that (de-)merit goods are goods (private or public) that are to be consumed at (lower or) higher levels than consumer sovereignty would entail (Edelman \& Opschoor, 1970). ${ }^{3}$

Environmental goods and services often fall in this category on informational and risk preference grounds, and, even more so, due to intertemporal or intergenerational considerations (James, Jansen, \& Opschoor, 1978; Opschoor, 1974): the wishes and interests of individuals capable of expressing them now may not exhaust all relevant ones. In the context of natural resources and environmental services one could think also of public concerns constraining the current use of these resources and services in order to make them available to future stakeholders, the setting aside of habitats on biodiversity protection grounds, etc. As the Dublin Action Programme (1992) put it: "Water is a vital part of the environment and a home for many forms of life (...) Integrated management of river basins provides the opportunity to

\footnotetext{
${ }^{2}$ Moreover, OECD (1987, 14ff.) mentioned the need to have pricing systems that are easily understood and acceptable to the consumers of water services.

${ }^{3}$ This definition differs from the one used by Schouten and Schultz, who define merit goods in terms of externalities and access.
} 
safeguard aquatic ecosystems, and make their benefits available to society on a sustainable basis". These systems should be protected and their integrity preserved vis-à-vis the apparent interests of current users, on grounds to do with their merits for stakeholders other than those presently active in water markets. Dublin seems to expect that this would result from 'managing water as an economic good' (see the text accompanying Principle 4). But to do so with the result hoped for would be better served by explicitly acknowledging the special merit-considerations mentioned above. Water resource management regimes must be made to provide adequate protection to the aquatic ecosystems and hydrological systems that generate the flow of water services.

Water provision and water resource oriented public policies are thus justifiable on a collection of grounds including merit-arguments to do with concerns over future provision, uncertainties over ecosystems characteristics, and concerns over biological (including ecological) diversity. Clearly, markets alone cannot be relied on. This has engendered a struggle to make water a public good "by design", ensuring that all have adequate access to it-which suggests the need to institutionalize access as a human right (Mehta, 2003, p. 557). Moreover, at the level of markets as social structures, power relations and knowledge asymmetries - and especially how these two relate to access and delivery-are becoming increasingly prominent in discussions on water.

Thus, water indeed is "a key area for social and public policy" (Mehta, 2003, p. 557) - and one of heated confrontation, as also Schouten and Schwartz would agree with Mehta. My point here is that to understand or describe all of this we do not really need new concepts such as "political goods" to present the predicaments of the water sector and investments in it.

\section{Investment in the water sector}

As Schouten and Schwartz argue, if MDG-goals on drinking water and sanitation services are to be met, substantial additional investments will need to be made. Up to US $\$ 100$ billion may be required globally above the present US\$ $30-80$ billion. Why do these funds not come to the sector? The authors hold that it is the politicized nature of the water sector that accounts for investment falling short of "sound and sustainable investment in water services". By the latter the authors probably mean: sustained flows of new and additional investment funds.

To answer the question why such flows do not come, one would need: (1) an analysis of possible sources of funding, and (2) of alternative directions in which such flows might go, as well as (3) an analysis of relative impediments and attractors for the various categories of potential investors in each of these directions. Of these, only the first one is addressed in its full width and the last one in part.

Schouten and Schwartz distinguish three main 'channels' of funding: the public sector, the private sector and the donor community $(70-75 \%, 20-25 \%$ and $5-10 \%$ of current investment, respectively). The authors hold that public funding suffers from a lack of means (a point also made by Mehta (2003)) and that governments tend to under-prioritize water and sanitation. They also note that apparently the private sector prefers to invest in other industries (e.g. telecommunications). On ODA, they observe a halving of aid flows to water from 1995 to 2002. Against the observed 
trends the authors put a recent (2004) estimate of the benefit-cost ratio of water and sanitation investments, in the order of 5 or more. The latter argument may be insufficiently convincing to tempt investors into the water sector, I would say, if: (1) the full societal benefits would not accrue to the investors (as typically is the case with market based pricing), or if (2) they felt forced to apply financially oriented investment analyses more than welfare economic ones (as is the case with public decision makers short of funds), and/or if (3) investors saw higher, or more reliable, financial (or even economic) returns elsewhere. A systematic probe into these aspects would help in providing a more comprehensive and profound answer to the question at hand. As it is, Schouten and Schwartz highlight once again one relevant aspect: the politicized nature of the structure of the water market. Theoretical developments (in evolutionary and institutional economics) more recent than the study they quote (Korbin, 1979) allow for potentially insightful deeper and broader analysis of investment behavior, its determinants and impediments.

\section{Conclusion}

Schouten and Schwartz ask why there is a level and pattern of investment in water services that lags behind the socially desirable, and why it is that investment strategies run into implementation hurdles. The politicized nature of the water sector is presented as the major cause of that. This may be true, but the analysis of investment behavior in the water sector should be made much deeper and wider before such a conclusion could really be drawn. Yet, the authors at least have a point in drawing attention to this feature. Power asymmetries, preferences (social and private) and interests, as well as ideologically or opportunistically based preferences for institutional forms of decision making and management of water systems, all are behind current systems of water provision and water management; they also feature in debates about water sector reform. Even though the notion of 'political goods' introduced by the authors may not be necessary for analytical and descriptive purposes, it may have advocacy value in drawing attention to some of the hurdles that proponents of adequate and affordable water and sustainable use of water resources will run into.

\section{References}

Edelman, F. J., \& Opschoor, J. B. (1970). Overheid en Merit Goods. Openbare Uitgaven, 2(2), 64-75. James, D. E., Jansen, H. M. A., \& Opschoor, J. B. (1978). Economic approaches to environmental problems: Techniques and results of empirical analysis. Amsterdam/Oxford/New York: Elsevier Scientific Publ.

Kaul, I., Conceicao, P., le Goulven, K., \& Mendoza, R. U. (Eds.) (2003). Providing global public goods. Oxford: Oxford University Press.

Mehta, L. (2003). Problems of publicness and access rights: Perspectives from the water domain. In I. Kaul, P. Conceicao, K. le Goulven, \& R. U. Mendoza (Eds.), Providing global public goods (pp. 556-575). Oxford: Oxford University Press.

Musgrave, R. A. (1959). The theory of public finance. McGraw-Hill. 
OECD (Organization for Economic Co-operation and Development) (1987). Pricing of water services. Paris: OECD.

Opschoor, J. B. (1974). Economische Waardering van Milieuverontreiniging. Dissertation. Assen/ Amsterdam: Van Gorcum.

Savenije, H. H. G., van der Zaag, P. (2001). Demand management and water as an economic good: Paradigms with pitfalls. Value of Water Research Report Series No. 8. Delft: Institute for Hydrological Engineering. 